David Rhys Axon, MPharm, MS

Graduate Research Associate

University of Arizona College of Pharmacy

1295 N Martin Ave

PO Box 210202

Tucson, Arizona, 85721

Phone +1(520)373-9381

axon@pharmacy.arizona.edu

Patrick Campbell, PharmD

Graduate Research Associate

University of Arizona College of Pharmacy

1295 N Martin Ave

PO Box 210202

Tucson, Arizona, 85721

Phone +1(520)204-5818

pcampbell@pharmacy.arizona.edu

Terri Warholak, PhD

Professor and Assistant Dean

University of Arizona College of Pharmacy

1295 N Martin Ave

PO Box 210202

Tucson, Arizona, 85721

Phone +1(520)235-5529

warholak@pharmacy.arizona.edu

Corresponding author: 
David Rhys Axon, MPharm, MS

Graduate Research Associate

University of Arizona College of Pharmacy

1295 N Martin Ave

PO Box 210202

Tucson, Arizona, 85721

Phone $+1(520) 373-9381$

axon@pharmacy.arizona.edu

\begin{abstract}
Introduction: Student pharmacists need to work in teams in the educational and practice settings, but there is limited information on their teamwork experiences in the published literature. The study objective was to assess second-year (P2) student pharmacists' teamwork experiences in an experiential quality improvement (QI) course.
\end{abstract}

Methods: A retrospective pre-post survey was conducted with P2 students to assess teamwork experience attitudes. Students reported their agreement with 17 statements about teamwork, first after the project was planned and again after the project was complete, and responded to four demographic questions. A Kuder-Richardson 20 score was calculated to assess internal consistency. Differences between pre- and post- groups for each teamwork item were assed using McNemar's test. An alpha level of 0.05 was used, and a Bonferroni correction was applied for multiple comparisons.

Results: Sixty P2 students (50\%) responded to the survey. After the project was complete, the majority indicated agreement with good teamwork qualities and disagreement with poor teamwork qualities for most items. More than $60 \%$ of respondents indicated they would like to do collaborative work again while $20 \%$ of respondents indicated imbalances in member contributions caused conflict within the team.

Conclusion: The majority of student pharmacists in this investigation had positive experiences working in teams with other student pharmacists, but new important findings from this study indicate that further work is needed to prevent imbalances in team-member contributions and to encourage students to work on future collaborative projects in some cases. 
Keywords: Student pharmacist; Teamwork; Student research; Quality improvement; Pharmacy research.

Conflict of interest: The authors have no conflicts of interest to declare.

Disclosure: The authors have no financial disclosures to declare. No funding was provided to conduct this research. 


\title{
Student pharmacists' experiences of teamwork in a quality improvement course
}

\begin{abstract}
Introduction: Student pharmacists need to work in teams in the educational and practice settings, but there is limited information on their teamwork experiences in the published literature. The study objective was to assess second-year (P2) student pharmacists' teamwork experiences in an experiential quality improvement (QI) course.
\end{abstract}

Methods: A retrospective pre-post survey was conducted with P2 students to assess teamwork experience attitudes. Students reported their agreement with 17 statements about teamwork, first after the project was planned and again after the project was complete, and responded to four demographic questions. A Kuder-Richardson 20 score was calculated to assess internal consistency. Differences between pre- and post- groups for each teamwork item were assed using McNemar's test. An alpha level of 0.05 was used, and a Bonferroni correction was applied for multiple comparisons.

Results: Sixty P2 students (50\%) responded to the survey. After the project was complete, the majority indicated agreement with good teamwork qualities and disagreement with poor teamwork qualities for most items. More than $60 \%$ of respondents indicated they would like to do collaborative work again while $20 \%$ of respondents indicated imbalances in member contributions caused conflict within the team.

Conclusion: The majority of student pharmacists in this investigation had positive experiences working in teams with other student pharmacists, but new important findings from this study indicate that further work is needed to prevent imbalances in team-member contributions and to encourage students to work on future collaborative projects in some cases.

Keywords: Student pharmacist; Teamwork; Student research; Quality improvement; Pharmacy research.

Conflict of interest: The authors have no conflicts of interest to declare.

Disclosure: The authors have no financial disclosures to declare. No funding was provided to conduct this research. 
Introduction

In the past, many healthcare professionals practiced independently. Nowadays, the complexities of modern healthcare require healthcare professionals to work collaboratively as part of a team to draw on each other's expertise. ${ }^{1}$ A team, at its most basic level, may be defined as two or more individuals who have specific roles and work on interdependent tasks in an adaptable fashion to achieve a common shared goal. ${ }^{2}$ Effective healthcare teams are necessary to provide quality patient care and ensure patient safety ${ }^{3-5}$ because of the increasing complexity and specialization of care, comorbidities, chronic diseases, and workforce shortages. ${ }^{6}$

Teamwork is a skill that requires training and cultivation in order for it to be effective. ${ }^{7}$ The Center for the Advancement of Pharmacy Education (CAPE) educational outcomes and the Accreditation Council for Pharmacy Education (ACPE) standards highlight the need for student pharmacists to be able to work as members of an interprofessional team. ${ }^{8-9}$ The University of Arizona College of Pharmacy, like many others across the United States, offers opportunities for student pharmacists to develop their teamwork skills in its curriculum to prepare students for their profession. For example, students are required to form and work in teams to complete Quality Improvement (QI) projects in their second year of the pharmacy program. Team-based learning supports students to learn at a higher, more meaningful level by applying their knowledge and developing their critical thinking skills to solve a problem, ${ }^{10}$ much like they will encounter in their future professional careers.

Previous research has examined teamwork among healthcare professionals and students, however most of this is from an interprofessional teamwork perspective. Student pharmacists' experiences of working as part of a team have not been well assessed. In particular, students' perceptions of working in teams to conduct scientific enquiries from inception to completion have not been reported in the pharmacy literature. It is not known what positive experiences they encounter and perhaps more importantly, what problems occur that need to be addressed in order to improve teamwork. Therefore, the objective of this study was to assess second year (P2) student pharmacists' experiences of teamwork conducting a QI project.

Methods

Study design: This study used a retrospective pre-post survey design to assess student pharmacists' attitudes about their teamwork experiences.

Inclusion criteria: In order to be included in this study, participants had to be a P2 student who 
worked as part of a team for their QI project at the University of Arizona College of Pharmacy.

The Quality Improvement course: The QI course consists of a two-credit class in the fall and a one-credit class in the spring of the second year of the professional pharmacy program. This course is mandatory and helps students meet several of the CAPE outcomes and ACPE standards. ${ }^{8-9}$ Student pharmacists are taught the concepts and examples of QI, while simultaneously forming groups and developing a project proposal in the fall semester. Students are given guidance on and participate in activities to form teams, establish team norms, effectively communicate with each other, and manage conflicts. In particular, students are required to read the textbook "Have a nice conflict: How to find success and satisfaction in the most unlikely places", ${ }^{11}$ and attend three one-hour interactive class sessions on team building and conflict management. During these sessions, students are expected to participate in and complete activities to help them with their team building and conflict management skills. Students are empowered to select their own team members without direction from the class instructor and then they are assigned to a preceptor (i.e., a practicing pharmacist, physician or nurse) who has a practice-based quality or safety problem that the students help address. Projects vary in scope, thus each team must use their intuition and adaptability to succeed much like they will need to do in their future professional practice. In the spring semester, students execute their QI project plans, and present their findings at a poster session in the last week of the semester.

Survey: The 21-item survey (Appendix 1) was developed using items from Hoegl and Gemuenden. ${ }^{12}$ A total of 17 items were statements about teamwork that required students to report their level of agreement (strongly agree, agree, disagree, strongly disagree) with the statement at two time points (i.e., 17 items, 34 responses): first, after the project was planned (pre-test); and second, after the project was complete (post-test). In addition, participants were asked to provide their age, gender, and previous teamwork experience. This information was used to describe the characteristics of the survey sample.

Data collection: Print-based surveys were distributed at the end of semester poster session in May 2017, an event where students presented the findings of their QI projects. At the beginning of the poster session, students were given a description of the study and were voluntarily invited to participate. Institutional Review Board approval was granted before data were collected.

Data analysis: Data were collected and entered into a Microsoft Excel® v.14.6.5 $5^{13}$ spreadsheet according to a codebook for analysis. A Kuder-Richardson 20 (KR-20) score was calculated to assess 
internal consistency of the teamwork scale, where a score greater than 0.7 was considered satisfactory. ${ }^{14}$ The differences between the pre- and post- groups for each teamwork item were assessed using McNemar's test. All statistical analyses were performed using SASß software v9.4. ${ }^{15}$ An alpha level of 0.05 set a priori was used, and a Bonferroni correction was used to determine statistical significance in the case of multiple comparisons. Therefore, significant differences between groups on any individual teamwork item were observed at a significance level of less than 0.003 .

Results

All P2 ( $n=120)$ students were invited to participate; $60(50.0 \%)$ students returned completed surveys. Participants had a mean age of $25.0( \pm 2.9)$ years. The majority were female $(55.1 \%)$ and had previously worked in a team (90.0\%).

For most of the teamwork items, the majority of respondents indicated agreement if the item was related to good teamwork qualities (e.g., there was frequent communication within the team), and disagreement if the item was related to poor teamwork qualities (e.g., there were personal conflicts within our team). The 17-item teamwork scale demonstrated satisfactory internal consistency, with a KR-20 score of 0.69 after the project was planned (pre-test), and 0.70 after the project was completed (post-test).

There were no statistically significant differences between responses at the two time points. After the project was planned (pre-test), the most commonly agreed upon item was "Project discussions were conducted constructively" (96.7\% agreement), while the least agreed upon item was "There were personal conflicts in our team" (16.7\%). After the project was completed (post-test), the most commonly agreed upon items were "There was frequent communication within the team", "Project discussions were conducted constructively", "Our team was able to reach consensus regarding important issues", "I learned important lessons from this project", and "Teamwork promotes professional growth" (90.0\%), while the least agreed upon item was "Imbalance of member contributions caused conflicts in our team" (20.0\%).

After the project was completed, $62 \%$ of respondents indicated that they would like to do this type of collaborative work again. In addition, $60 \%$ of respondents indicated that their project required little re-working. Additional information about the student pharmacists' responses to each of the teamwork items is provided in Table 1.

Discussion 
One of the main findings from our study was that the majority of students indicated positive teamwork experiences for most of the items asked. For example, participants reported frequent communication within the team and respected team members' contributions. These are important characteristics of effective healthcare teams ${ }^{16}$ that enable healthcare professionals to communicate effectively for collaborative practice ${ }^{17}$ and to ensure patient safety. ${ }^{18}$ As part of the QI course curriculum, instruction was provided on effective team management such as communication techniques, personality differences, conflict management and establishing team norms, which may explain the high agreement with effective team characteristics.

Our study also demonstrated the benefits of team-based learning as most students reported that they were able to gain important new knowledge and learned important lessons by working on their projects. This may help them become better practitioners and improve patient outcomes. One of the important new findings from our study was that pharmacy students recognized the importance of teamwork skills to promote personal and professional growth. This finding also advocates for the inclusion of teamwork activities in the pharmacy curriculum to enable participation in successful teams in future.

Our study also identified some important new findings that add to the literature and may have implications for improving the provision and experiences of teamwork for student pharmacists. For example, after the project was completed almost $40 \%$ of students indicated that they did not want to participate in a collaborative project again, $20 \%$ reported that an imbalance in member contributions caused conflict within the team, and $25 \%$ noted that some students were not integrated into the team. This may reflect the reality of different personalities and working styles, which are factors that should be considered when forming teams in the future. However, these factors can be difficult to manage in situations where individuals are assigned to teams, as is often the case in practice.

Healthcare professionals should be trained to work collaboratively to become competent healthcare professionals who understand each other's roles. ${ }^{19}$ Although students are given instruction and activities to help them develop their teams, further guidance may be necessary. Lencioni ${ }^{20}$ has identified five characteristics that cause dysfunction in a team: absence of trust, fear of conflict, lack of commitment, avoidance of accountability, and inattention to results. Training students on overcoming some of these factors may be helpful. For example, students could review Tuckman's ${ }^{21-22}$ model of team development that includes forming, storming, norming, and performing, and was later updated to 
include adjourning. Guided by this framework, students may be better able to appreciate where they are as a team, and identify ways in which they can address any issues that arise.

Research has shown that teams who anticipate the need for conflict resolution and develop strategies to overcome it are successful over time. ${ }^{23}$ Therefore, students should realize that conflict might occur in their teams and should determine how best to resolve it in order to improve their teams' outcomes. For example, students could incorporate resolutions for inconsistent contributions from team members into their team norms.

Becoming an expert team player is a career-long learning process ${ }^{24}$ Therefore, gaining handson experience this early in their professional careers in a real-life setting may be beneficial in the long term. However, it is perhaps not surprising that these early experiences leave some students preferring not to participate again if they have had a bad experience. In an attempt to mitigate problems, students were required to complete brief reflections of their contributions and discuss team functionality several times throughout the semester. Research has found that students at one college of pharmacy in Canada were interested in future interprofessional training ${ }^{25}$ so it may be prudent to offer further teamwork training to our students as well.

Another new study finding was that two-fifths of student pharmacists reported that their project required some re-work. Ofstad and Brunner ${ }^{26}$ identified that teamwork exercises can feel artificial unless students grapple with authentic challenges. Therefore, re-working a project may have created a more immersive and authentic teamwork experience while providing valuable insight into the reality of teamwork. These projects provide students with opportunities to revise their projects for submission to national meetings, where they have an opportunity to present and gain feedback on their team project. These experiences may be beneficial for students when they enter professional practice or further training such as residency or fellowship programs.

Student responses indicated no significant differences between project planning and project completion, indicating they rated the experiences of teamwork in each part of the process equally. For example, students reported that both planning and completing the project contributed to professional development and personal growth. This finding could be communicated to the next cohort of students enrolled in the QI course to portray the benefit of their team projects. In addition, the findings of this study will be used in periodic reviews of the QI course (and college) curriculum to improve the teaching and real-world experiences of future students. 
There were limitations with this study, including those inherent to survey research such as participants understanding the questions and answering them accurately. Although the retrospective pre-post design minimizes response shift bias, ${ }^{27}$ recall bias may have influenced responses if respondents could not accurately recall their opinions due to the time that passed since the event. The response rate of $50 \%$ may bias the results, and the small sample size of student pharmacists at one college of pharmacy may not be generalizable to all student pharmacists or other healthcare professionals engaged in teamwork. However, this study illustrates a model through which students can engage in teamwork to prepare them for their future professional practice. In addition, students were able to select their own teams. This may not reflect the reality of practice where individuals have to work in teams based on the needs of the patient.

Future work could include investigating the reasons behind some of the findings such as why students do not want to participate in collaborative projects, or exploring the reasons why conflicts developed within teams. A similar study could be conducted with teams that did not select their own members, and the findings compared to those from our study. Moving forward, pharmacy curricula should continue to provide opportunities for students to develop their teamwork skills, but faculty should also be aware of the factors that can affect team dynamics.

Conclusions

The majority of student pharmacists in this investigation had positive experiences of working in teams with other student pharmacists, and agreed that teamwork allowed for the ability to gain important know-how and opportunities for personal and professional growth. Important new findings from this study were that greater effort is needed to integrate team members, prevent imbalances in team-member contributions, and to encourage more students to work on collaborative projects in future.

\section{References}

1. Mitchell P, Wynia M, Golden R, et al. Core principles and values of effective team-based health care. Institute of Medicine. https://www.nationalahec.org/pdfs/vsrt-team-based-careprinciples-values.pdf Published October 2012. Accessed 5 June 2017. 
2. Salas E, Dickinson TL, Converse SA. Toward an understanding of team performance and training. In: Swezey RW, Salas E, ed. Teams: Their Training and Performance. Norwood, NJ: Ablex; 1992:3-29.

3. Pham JC, Aswani MS, Rosen M, et al. Reducing medical errors and adverse events. Annu Rev Med. 2012; 63(1):447-463.

4. Manser T. Teamwork and patient safety in dynamic domains of healthcare: a review of the literature. Acta Anaesthesiol Scand. 2009; 53(2):143-151.

5. Baker DP, Gustafson S, Beaubien J, Salas E, Barach P. Medical Teamwork and patient safety: the evidence-based relation. Agency for Healthcare Research and Quality. https://archive.ahrq.gov/research/findings/final-reports/medteam/ Published July 2005. Accessed 5 June 2017.

6. World Health Organization. Patient safety curriculum guide: multi-professional education. World Health Organization. http://apps.who.int/iris/bitstream/handle/10665/44641/9789241501958 eng.pdf;jsessionid=0F 2548A8966E23896F5699A7E7F9523C?sequence=1 Published 2011. Accessed 3 August 2018.

7. Clancy CM, Tornberg DN. TeamSTEPPS: assuring optimal teamwork in clinical settings. Am J Med Qual. 2007; 22(3):214-217.

8. Medina MS, Plaza CM, Stowe CD, et al. Center for the advancement of pharmacy education (CAPE) educational Outcomes 2013. Am J Pharm Educ. 2013;77(8). doi: 10.5688/ajpe778162.

9. Accreditation Council for Pharmacy Education. Accreditation standards and key elements for the professional program in pharmacy leading to the doctor of pharmacy degree ("standards 2016"). Accreditation Council for Pharmacy Education. https://www.acpeaccredit.org/pdf/Standards2016FINAL.pdf Published February 2015. Accessed 5 June 2017.

10. Gordon J. Fostering students' personal and professional development in medicine: a new framework for PPD. Med Educ. 2003; 37(4):341-349.

11. Scudder T, Patterson M, Mitchell K. Have a Nice Conflict: how to Find Success and Satisfaction in the Most Unlikely Places - a Fable. San Francisco, CA: Jossey Bass; 2012:1-233. 
12. Hoegl M, Gemuenden HG. Teamwork quality and the success of innovative projects: a theoretical concept and empirical evidence. Organ Sci. 2001; 12(4):435-449.

13. Microsoft Excel巴 [computer program]. Version 14.6.5. Redmond, WA: Microsoft Corporation; 2010.

14. Kuder GF, Richardson MW. The theory of the estimation of test reliability. Psychometrika. 1937; 2(3):151-160.

15. SAS $®$ [computer program]. Version 9.4. Cary, NC: SAS Institute Inc; 2013.

16. Mickan SM, Rodger SA. Effective health care teams: a model of six characteristics developed from shared perceptions. J Interprof Care. 2005; 19(4):358-370.

17. Suter E, Arndt J, Arthur N, Parboosingh J, Taylor E, Deutschlander S. Role understanding and effective communication as core competencies for collaborative practice. J Interprof Care. 2009; 23(1):41-51.

18. Brock D, Abu-Rish E, Chiu CR, et al. Interprofessional education in team communication: working together to improve patient safety. BMJ Qual Saf. 2013; 22(5):414-423.

19. Maharajan MK, Rajiah K, Khoo SP, et al. Attitudes and readiness of students of healthcare professions towards interprofessional learning. PloS One. 2017; 12(1). doi: 10.1371/journal.pone.0168863.

20. Lencioni P. The Five Dysfunctions of a Team: A Leadership fable. San Francisco, CA: Jossey Bass; 2002:185-195.

21. Tuckman BW. Developmental sequence in small groups. Psychological Bulletin. 1965; 63(6):384-399.

22. Tuckman BW, Jensen MC. Stages of small-group development revisited. Group Organ Manag. 1977; 2(4):419-427.

23. Behfar KJ, Peterson RS, Mannix EA, Trochim WM. The critical role of conflict resolution in teams: a close look at the links between conflict type, conflict management strategies, and team outcomes. J Appl Psychol. 2008; 93(1):170-88.

24. Salas E, Rosen MA. Building high reliability teams: progress and some reflections on teamwork training. BMJ Qual Saf. 2013; 22(5):369-373. 
25. Del Bigio S, Mulhall S, Shevchuk Y, Mansell H. Perceptions of teamwork and interprofessional education in undergraduate pharmacy students. Pharmacy Education. 2016; 16(1):199-209.

26. Ofstad W, Brunner LJ. Team-based learning in pharmacy education. Am J Pharm Educ. 2013; 77(4): Article 70.

27. Howard GS, Schmeck RR, Bray JH. Internal validity in studies employing self-report instruments: a suggested remedy. J Educ Meas. 1979; 16:129-35. 
Appendix 1

Please respond to the following items by placing a check mark $(\mathcal{})$ in the box that best represents your views:

1) After the project was planned (proposal submission) $\underline{\text { AND }}$

2) After the project was complete (final report submission).

\begin{tabular}{|c|c|c|c|c|c|c|c|c|c|}
\hline \multirow[b]{2}{*}{ \# } & \multirow[b]{2}{*}{ Item } & \multicolumn{4}{|c|}{$\begin{array}{l}\text { After the project was planned } \\
\text { (proposal submission) }\end{array}$} & \multicolumn{4}{|c|}{$\begin{array}{l}\text { After the project was complete } \\
\text { (final report submission) }\end{array}$} \\
\hline & & $\begin{array}{l}\text { Strongly } \\
\text { Agree }\end{array}$ & Agree & Disagree & $\begin{array}{l}\text { Strongly } \\
\text { Disagree }\end{array}$ & $\begin{array}{l}\text { Strongly } \\
\text { Agree }\end{array}$ & Agree & Disagree & $\begin{array}{l}\text { Strongly } \\
\text { Disagree }\end{array}$ \\
\hline 1 & $\begin{array}{l}\text { There was frequent communication within } \\
\text { the team }\end{array}$ & & & & & & & & \\
\hline 2 & $\begin{array}{l}\text { I was happy with the timeliness in which I } \\
\text { received information from other team } \\
\text { members }\end{array}$ & & & & & & & & \\
\hline 3 & $\begin{array}{l}\text { I was happy with the quality of the } \\
\text { information I received from other team } \\
\text { members. }\end{array}$ & & & & & & & & \\
\hline 4 & $\begin{array}{l}\text { Imbalance of member contributions caused } \\
\text { conflicts in our team. }\end{array}$ & & & & & & & & \\
\hline 5 & $\begin{array}{l}\text { Project discussions were conducted } \\
\text { constructively. }\end{array}$ & & & & & & & & \\
\hline 6 & $\begin{array}{l}\text { Suggestions and contributions of team } \\
\text { members were respected. }\end{array}$ & & & & & & & & \\
\hline 7 & $\begin{array}{l}\text { Our team was able to reach consensus } \\
\text { regarding important issues. }\end{array}$ & & & & & & & & \\
\hline 8 & $\begin{array}{l}\text { All members were fully integrated in our } \\
\text { team. }\end{array}$ & & & & & & & & \\
\hline 9 & There were personal conflicts in our team. & & & & & & & & \\
\hline 10 & The project can be regarded as successful & & & & & & & & \\
\hline 11 & I am satisfied with the project result & & & & & & & & \\
\hline 12 & The project required little re-work & & & & & & & & \\
\hline 13 & $\begin{array}{l}\text { I would like to do this type of collaborative } \\
\text { work again. }\end{array}$ & & & & & & & & \\
\hline 14 & $\begin{array}{l}\text { I was able to acquire important know-how } \\
\text { through this project. }\end{array}$ & & & & & & & & \\
\hline 15 & I learned important lessons from this project. & & & & & & & & \\
\hline
\end{tabular}




\begin{tabular}{|l|l|l|l|l|l|l|l|l|}
\hline 16 & Teamwork promotes personal growth. & & & & & & & \\
\hline 17 & Teamwork promotes professional growth. & & & & & & \\
\hline
\end{tabular}

Please respond to the following demographic questions:

18. What is your age? ___ years

19. What is your gender? Male or Female?

20 . What is your race?
$\square$ White
$\square$ Asian
$\square$ Hispanic or Latino
$\square$ Other

21. Have you previously worked as part of a team to complete a project? Yes or No? 
Table 1. Student Pharmacists' Responses to each of the Teamwork Items After the Project was

\begin{tabular}{|c|c|c|c|}
\hline & Item & $\begin{array}{l}\text { After the project } \\
\text { was planned } \\
\text { (Proposal } \\
\text { submission) } \\
\text { Strongly } \\
\text { agree/agree } \\
\mathrm{N}(\%)\end{array}$ & $\begin{array}{l}\text { After the project } \\
\text { was complete } \\
\text { (Final report } \\
\text { submission) } \\
\text { Strongly } \\
\text { agree/agree } \\
\mathrm{N}(\%)\end{array}$ \\
\hline 1 & $\begin{array}{l}\text { There was frequent communication within the team } \\
\text { I was happy with the timeliness in which I received }\end{array}$ & $56(93.3)$ & $54(90.0)$ \\
\hline 2 & $\begin{array}{l}\text { information from other team members } \\
\text { I was happy with the quality of the information I }\end{array}$ & $54(90.0)$ & 47 (78.3) \\
\hline 3 & $\begin{array}{l}\text { received from other team members } \\
\text { Imbalance of member contributions caused conflicts }\end{array}$ & $53(88.3)$ & $48(80.0)$ \\
\hline 4 & in our team & $15(25.0)$ & $12(20.0)$ \\
\hline 5 & $\begin{array}{l}\text { Project discussions were conducted constructively } \\
\text { Suggestions and contributions of team members }\end{array}$ & $58(96.7)$ & $54(90.0)$ \\
\hline 6 & $\begin{array}{l}\text { were respected } \\
\text { Our team was able to reach consensus regarding }\end{array}$ & $57(95.0)$ & $50(83.3)$ \\
\hline 7 & important issues & $56(93.3)$ & $54(90.0)$ \\
\hline 8 & All members were fully integrated in our team & 55 (91.7) & $45(75.0)$ \\
\hline 9 & There were personal conflicts in our team & $10(16.7)$ & $13(21.7)$ \\
\hline 10 & The project can be regarded as successful & $53(88.3)$ & $50(83.3)$ \\
\hline 11 & I am satisfied with the project result & 49 (81.7) & $43(71.7)$ \\
\hline 12 & $\begin{array}{l}\text { The project required little re-work } \\
\text { I would like to do this type of collaborative work }\end{array}$ & 42 (70.0) & $36(60.0)$ \\
\hline 13 & $\begin{array}{l}\text { again } \\
\text { I was able to acquire important know-how through }\end{array}$ & $45(75.0)$ & 37 (61.7) \\
\hline 14 & this project & $54(90.0)$ & $52(86.7)$ \\
\hline 15 & I learned important lessons from this project & 55 (91.7) & $54(90.0)$ \\
\hline 16 & Teamwork promotes personal growth & $53(88.3)$ & $52(86.7)$ \\
\hline 17 & Teamwork promotes professional growth & 55 (91.7) & $54(90.0)$ \\
\hline
\end{tabular}

No statistical significance between the two time points (pre- and post-test). 